\title{
Accelerating the Deactivation of Salmonella enterica Serovar Newport and Escherichia coli 0157:H7 in Dairy Manure by Modifying pH or Temperature
}

\author{
John D. Toth ${ }^{*}, 1$, Helen W. Aceto ${ }^{1}$, Shelley C. Rankin ${ }^{2}$, Chitrita DebRoy ${ }^{3}$ and Zhengxia Dou ${ }^{1}$ \\ ${ }^{I}$ University of Pennsylvania, School of Veterinary Medicine, Department of Clinical Studies, New Bolton Center, 382 \\ West Street Rd., Kennett Square, PA 19348, USA \\ ${ }^{2}$ Department of Pathobiology, School of Veterinary Medicine, University of Pennsylvania, USA \\ ${ }^{3}$ Department of Veterinary and Biomedical Sciences, College of Agricultural Sciences, Pennsylvania State University, \\ 104 Wiley Lab, Wiley Lane, University Park, PA 16802, USA
}

\begin{abstract}
To assess methods for control of disease-causing bacteria in animal manures prior to field application, we manipulated the temperature or adjusted $\mathrm{pH}$ of dairy manure to high (3.5 to 5) or low (10 to 12$)$ values with aluminum sulfate or hydrated lime, and inoculated the manure with Salmonella enterica serovar Newport or Escherichia coli O157:H7, then incubated the manure at ambient temperature. At $\mathrm{pH} \leq 4.2, S$. Newport was eliminated within 6 days; however at $\mathrm{pH}>4.2 \mathrm{~S}$. Newport was suppressed only temporarily and recovered to concentrations near the unamended controls. $\mathrm{pH}$ required to eliminate $E$. coli $\mathrm{O} 157: \mathrm{H} 7$ was $\leq 4.5$. Both pathogens were killed by $\mathrm{pH} \geq 11.0$. The pathogens were eliminated within 2 weeks when inoculated manure was incubated at $37^{\circ} \mathrm{C}$, whereas at $22^{\circ} \mathrm{C}$ and $4^{\circ} \mathrm{C}$, the organisms persisted for much longer periods. $S$. Newport survived for over 300 days at $4^{\circ} \mathrm{C}$, which has implications for manure spreading in colder seasons.
\end{abstract}

Keywords: Dairy manure, Salmonella, E. coli O157:H7, pathogen deactivation.

\section{INTRODUCTION}

Movement of zoonotic pathogenic microorganisms from animal production systems into the human food chain through land-spreading of animal manures can potentially lead to foodborne illness. Incidences of foodborne diseases have generated any number of media headlines. The Centers for Disease Control and Prevention, U.S. Department of Health and Human Services, estimate that the total burden of foodborne illness is 48 million cases annually in the U.S., 128 thousand hospitalizations, and 3000 deaths [1]. Shiga toxin-producing strains of Escherichia coli, including O157:H7 (E. coli O157:H7), are estimated to cause 265 thousand cases of foodborne illness per year in the US. Salmonella enterica serovar Newport (S. Newport) has in the past decade increased its presence in dairy cattle, and has been characterized as an emerging disease-causing agent [2]. Together, nontyphoidal strains of Salmonella and E. coli O157:H7 are among the top five pathogens leading to the greatest number of hospitalizations for foodborne illness. Recent high-profile cases have been reported as due to consuming pathogen-contaminated sprouts in Germany, and lettuce and spinach in the U.S.

Dairy cattle are important reservoirs for both pathogenic E. coli and Salmonella [3, 4]. Dairy manures when landapplied are a point of entry for the pathogenic organisms in

*Address correspondence to this author at the Center for Animal Health and Productivity, New Bolton Center, 382 West Street Road, Kennett Square, PA, 19348, USA; Tel: 1-610-925-6327; Fax: 1-610-925-6823;

E-mail: jdtoth@vet.upenn.edu the agroecosystem, where they have been found to survive for months. Using environmental sentinel chambers [5], which allow equilibration of pathogens with ambient environmental moisture and gas exchange conditions while preventing their dissemination with semi-permeable membranes, Toth et al. [6] found that $S$. Newport survived for $>9$ months in a grass field and $>6$ months in a dairy effluent lagoon. The general pattern of $S$. Newport deactivation in the dairy farm environment was a log-linear decline with $\log$ reduction times (time for 10-fold deactivation) of 14 to 20 days in the soil and 7 days in the lagoon, followed by longer-term survival at low and variable concentrations. However, in a static dairy solids compost pile, the pathogens were killed by temperatures exceeding $60^{\circ} \mathrm{C}$ within one day [6].

Reducing pathogen loads on the farm prior to field spreading of manure can be a potential useful complement to adhering to proper hygiene in the human food chain, in addition to following prescribed food production practices such as a Hazard Analysis and Critical Control Points protocols [7]. Various manure treatments have been suggested as ways to decrease pathogens in manure, for example, through lowering manure $\mathrm{pH}[8]$ or increasing $\mathrm{pH}$ [9]. In the present study, manure $\mathrm{pH}$ adjustment was achieved using two chemicals commonly used in dairy production, aluminum sulfate (alum, $\mathrm{Al}_{2}\left(\mathrm{SO}_{4}\right)_{3} \bullet 14 \mathrm{H}_{2} \mathrm{O}$ ) and hydrated lime $\left(\mathrm{CaOH}_{2}\right)$. Alum is used in food animal production systems to bind soluble manure phosphorus [10, 11], and hydrated lime has been shown to reduce the population of mastitis-causing bacteria when applied on mattresses or to bedding [12]. Another treatment option 
effectively killing pathogenic bacteria is manure composting $[6,13]$, a process largely driven by thermal deactivation. This paper reports the survival and die-off characteristics of $S$. Newport and E. coli O157:H7 in dairy manure when treated with alum, hydrated lime, or with temperature adjustment in laboratory incubation studies. The results illustrated an accelerated deactivation of these pathogens at higher temperature or when the $\mathrm{pH}$ was adjusted to certain threshold levels.

\section{MATERIALS AND METHODOLOGY}

\subsection{Manure and Manure Treatments}

Manure from healthy, lactating Holstein cows was obtained from the floor of a free-stall dairy immediately following excretion. The cows were fed a total mixed ration including corn (maize) silage, grass hay, corn grain and protein mix. The bulk manure samples, consisting largely of feces plus possibly small amounts of urine and wood shavings bedding material, were stored frozen at $-20^{\circ} \mathrm{C}$ until laboratory usage. Manure samples averaged $0.143 \mathrm{~g} \mathrm{~g}^{-1}$ dry matter.

Alum or hydrated lime used to lower or increase $\mathrm{pH}$ of dairy manure were in their technical grade formulations. Bulk manure samples with $\mathrm{pH}$ values of 7.0 to 7.3 were amended with alum to achieve $\mathrm{pH}$ in the range 3.5 to 6 , or with hydrated lime to reach the $\mathrm{pH}$ range 8 to 12 . Following chemical amendment, initial $\mathrm{pH}$ was measured on 1:1 ratio manure:deionized water mixtures, then $400 \mathrm{~g}$ amended manure samples in sterile, $1 \mathrm{~L}$ Nalgene beakers were inoculated with the pathogens $S$. Newport or E. coli O157:H7 at a target rate of $7 \log _{10}$ colony-forming units (CFU) $\mathrm{g}^{-1}$ manure, approximating a concentration shed by a heavily-infected animal [14]. Treatment beakers were covered with parafilm to retard moisture loss and incubated at ambient temperature with periodic sampling over a time course of 30 to 40 days. There were three replications of each $\mathrm{pH}$ or temperature treatment; an uninoculated beaker served for periodic monitoring of $\mathrm{pH}$ changes over the course of the incubation.

Preliminary trials were performed with $\mathrm{pH}$ adjusted to 4 , 5 or 6 with alum and $\mathrm{pH} 8,9$ or 10 with hydrated lime, designed to estimate approximate $\mathrm{pH}$ values effective in pathogen suppression. To determine if addition of alum or hydrated lime altered the temperature of the inoculated manure, temperature was monitored over the first $120 \mathrm{~min}$ following chemical addition. The chemicals had no effect on manure temperature. The main experiments were designed to determine $\mathrm{pH}$ lethal to the pathogens (indicated by elimination of the pathogens within 1 week without regrowth thereafter), with $\mathrm{pH}$ adjusted to 3.5 to 5 and 10 to 12 . On a per-kilogram manure basis, $31,39,45,48$, and $55 \mathrm{~g}$ alum were used to reach $\mathrm{pH}$ values of $4.9,4.5,4.2,4.0$, and 3.6, respectively; corresponding amounts of hydrated lime were $4.3,4.7,5.5,5.7$, and $7.2 \mathrm{~g}$ for $\mathrm{pH}$ of $10.0,10.3,10.8,11.0$, and 12.0 .

For the temperature adjustment trials, $400 \mathrm{~g}$ inoculated manure samples in sterile Nalgene beakers in triplicate were incubated in the dark at $4^{\circ} \mathrm{C}$ in a constant-temperature chamber, $22^{\circ} \mathrm{C}$ at ambient room temperature, and $37^{\circ} \mathrm{C}$ in an incubator.

\subsection{Bacteria Inoculation and Enumeration}

E. coli O157:H7 (ATCC standard 43895) was obtained from Penn State University's E. coli Reference Center. The strain was positive for Shiga toxins 1 and 2, and labeled with green fluorescence protein $(g f p ;[15])$. To propagate, a small amount of pure culture from a slant tube was transferred aseptically to $40 \mathrm{~mL}$ of Luria-Bertani broth (LB) in centrifuge tubes and incubated $24 \mathrm{hr}$ at $37^{\circ} \mathrm{C}$. Following incubation, the tubes were centrifuged $20 \mathrm{~min}$ at $2700 \times \mathrm{g}$. The supernatant was decanted, the pellet washed with dilute buffered peptone water (BPW, 0.1\%), then the bacteria were resuspended with vortexing in $40 \mathrm{~mL}$ BPW.

$S$. Newport (SRC isolate 0007-33) of dairy cattle origin was obtained from the University of Pennsylvania's Salmonella Reference Center. Propagation was similar to that for E. coli O157:H7, except that the pure culture was incubated in $40 \mathrm{~mL}$ brain-heart infusion (BHI) broth for 24 $\mathrm{hr}$, then $1 \mathrm{~mL}$ of the initial inoculum was added to $40 \mathrm{~mL}$ $\mathrm{BHI}$, incubated a further $24 \mathrm{hr}$, centrifuged and resuspended in $40 \mathrm{~mL}$ physiological saline solution (PSS; $8.5 \mathrm{~g} \mathrm{NaCl} \mathrm{L}^{-1}$ ). Pathogen inocula were stored at $4{ }^{\circ} \mathrm{C}$ until use in the survival trials.

For each sampling during the $\mathrm{pH}$ or temperature adjustment trials, inoculated manure was homogenized thoroughly with a sterile wooden spatula, then a $2 \mathrm{~g}$ subsample was added to a $50 \mathrm{~mL}$ centrifuge tube with $18 \mathrm{~mL}$ sterile PSS, and the tube agitated vigorously by hand then shaken $6 \mathrm{~min}$ at $150 \mathrm{~min}^{-1}$. For enumeration, aliquots were serially diluted in PSS at 1:10 ratios to bracket the expected countable concentration. $S$. Newport was plated on xyloselysine-deoxycholate (XLD) agar and E. coli O157:H7 on MacConkey's agar with sorbitol. Fluorescing E. coli colonies were counted on a transilluminator under ultraviolet light at $350 \mathrm{~nm}$. Thirty to 300 colony-forming units (CFU) per plate were considered optimal numbers for enumeration. After the pathogens were no longer detectable by direct plating (detection limit approximately $100 \mathrm{CFU} \mathrm{g}^{-1}$ ), a modification of the most-probable number method (MPN) was used [16]. Plate counts were converted to $\log _{10} \mathrm{CFU} \mathrm{g} \mathrm{g}^{-1}$ manure.

\subsection{Data Analysis}

Pathogen die-off as a function of $\mathrm{pH}$ or temperature treatments was modeled as a linear first-order deactivation using PROC GLM in SAS [17]. Differences in deactivation rate parameters were tested by covariance analysis in PROC GLM, and mean separation at $\mathrm{P}=0.05$ was determined by Fisher's protected lsd test where appropriate, following leastsquares analysis of variance.

\section{RESULTS}

\subsection{Chemical Amendment Effects on Manure pH}

The initial $\mathrm{pH}$ in the unamended control was 7.0, which varied little over the 14 days of monitoring, ranging from 6.9 to 7.1. In the treatments receiving higher rates of alum (achieving initial $\mathrm{pH}$ of $\leq 4.2$ ), the $\mathrm{pH}$ values increased by up to 1 unit but did not approach the circumneutral $\mathrm{pH}$ of the control (Fig. 1). Similarly, at the higher hydrated lime applications $(\mathrm{pH} \geq 11), \mathrm{pH}$ declined by approximately 


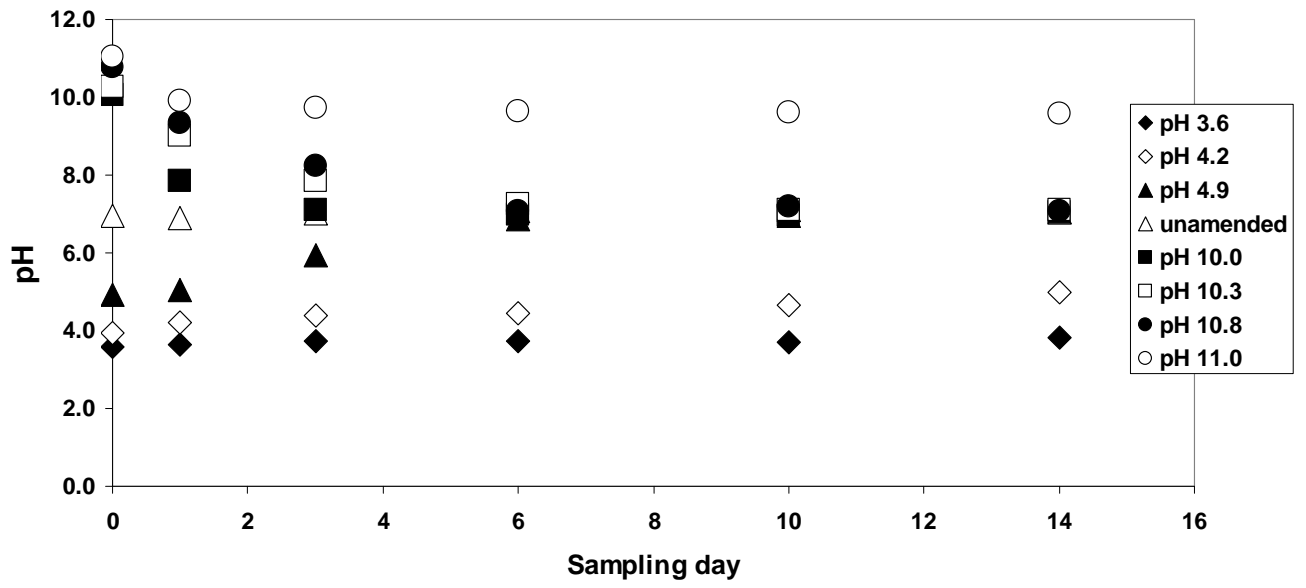

Fig. (1). Time trends in $\mathrm{pH}$ of dairy manure amended with alum or hydrated lime.

1.3 units through day 3 , remaining steady thereafter. At these highest and lowest $\mathrm{pH}$ treatments, all enteric bacteria activity was strongly suppressed or halted. However, at intermediate rates, manure $\mathrm{pH}$ gradually normalized to the $\mathrm{pH}$ of the unamended control within six days; the trend and time course were similar in $S$. Newport and E. coli O157:H7. Biotic activity of the microbial communities in the manure and high organic matter content were likely the causes of the convergence of $\mathrm{pH}$ at the intermediate treatment rates.

\section{2. pH Effects on Suppression of $S$. Newport and $E$. coli 0157:H7}

Preliminary trials established that at $\mathrm{pH} 4$ there was a significant reduction in $S$. Newport in dairy manure, with smaller and transient effects at $\mathrm{pH} 5$ and 10 (data not presented). The main experiments were designed to identify suppressing and lethal $\mathrm{pH}$ values. In the $\mathrm{pH} 3.6$ and 4.2 treatments, $S$. Newport concentrations showed some suppression within $2 \mathrm{hrs}$ of the addition of alum; the pathogen died off completely by day 6 (Fig. 2A). At pH 4.5 and 5.0, $\mathrm{S}$. Newport showed an initial reduction by up to 2.2 $\log$ units, but with a quick rebound to near the concentration in the unamended control by day 7 (Fig. 2A). After this rapid-change phase, $S$. Newport at $\mathrm{pH} 4.5$ and 5.0 declined in a log-linear pattern at rates of 0.10 to 0.12 day $^{-1}$, not significantly different from the unamended control (Table 1). This decline continued over the period of observation to day 30 .
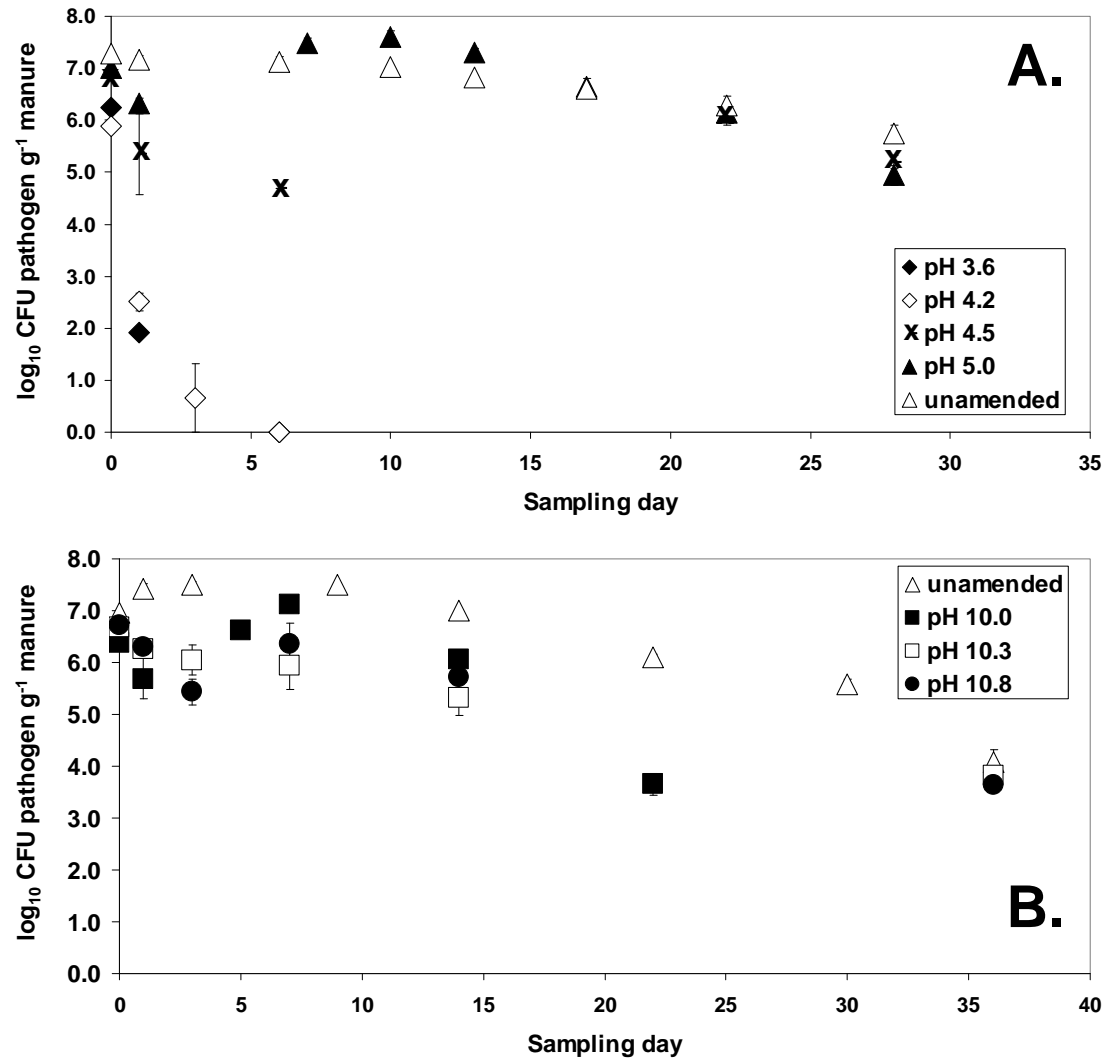

Fig. (2). $S$. Newport response to low $\mathrm{pH}$ (alum, A) and high $\mathrm{pH}$ (hydrated lime, B) amendment in dairy manure. Error bars represent \pm 1 standard error of the mean. Inoculated $S$. Newport was immediately eliminated by the $\mathrm{pH} 11$ and 12 treatments, not detected at the initial pathogen enumeration within 2 hours of hydrated lime application. 
Table 1. Regression Equation Parameters for the Log-Linear Decline Phase of $E$. coli $0157: \mathrm{H} 7$ and $S$. Newport Response to Modification of Dairy Manure pH

\begin{tabular}{|c|c|c|c|}
\hline pH Treatment & Initial pH & Slope & Y-Intercept \\
\hline$S$. Newport & 3.6 & $-{ }^{\mathrm{a}}$ & - \\
\hline \multirow[t]{4}{*}{ Low $\mathrm{pH}$} & 4.2 & - & - \\
\hline & 4.5 & -0.098 & 8.05 \\
\hline & 5.0 & -0.119 & 8.69 \\
\hline & 7.3 (unamended) & -0.117 & 8.56 \\
\hline$S$. Newport & 7.0 (unamended) & $-0.112 b$ & $8.58 \mathrm{~b}$ \\
\hline \multirow[t]{5}{*}{ High pH } & 10.0 & $-0.247 \mathrm{c}$ & $9.07 \mathrm{~b}$ \\
\hline & 10.3 & $-0.072 \mathrm{ab}$ & $6.39 \mathrm{a}$ \\
\hline & 10.8 & $-0.058 \mathrm{a}$ & $7.02 \mathrm{a}$ \\
\hline & 11.0 & - & - \\
\hline & 12.0 & - & - \\
\hline E. coli $\mathrm{O} 157: \mathrm{H} 7$ & 4.0 & - & - \\
\hline \multirow[t]{3}{*}{ Low $\mathrm{pH}$} & 4.5 & - & - \\
\hline & 4.9 & $-0.017 \mathrm{a}$ & $4.76 \mathrm{a}$ \\
\hline & 7.0 (unamended) & $-0.077 b$ & $7.96 \mathrm{~b}$ \\
\hline E. coli $\mathrm{O} 157: \mathrm{H} 7$ & 7.0 (unamended) & -0.078 & $7.95 b$ \\
\hline \multirow[t]{5}{*}{ High $\mathrm{pH}$} & 10.0 & -0.048 & $3.26 \mathrm{a}$ \\
\hline & 10.3 & -0.073 & $3.47 \mathrm{a}$ \\
\hline & 10.8 & -0.075 & $3.57 \mathrm{a}$ \\
\hline & 11.0 & - & - \\
\hline & 12.0 & - & - \\
\hline
\end{tabular}

${ }^{a}$ Dashes indicate $\mathrm{pH}$ adjustment treatments for which no linear regression equation could be generated.

Values for the same regression parameter, bacterial species and $\mathrm{pH}$ treatment followed by the same letter are not significantly different at the 5\% probability level by Fisher's protected lsd test following least-squares analysis of variance.

With hydrated lime raising manure $\mathrm{pH}$ to 11 or $12, \mathrm{~S}$. Newport was completely eliminated in the samples collected on the day of treatment application. At $\mathrm{pH} 10.0,10.3$ or 10.8 , $S$. Newport concentration declined by about $2 \log$ units in the first 3 days as compared to the unamended control (Fig. 2B). After the initial decline, $S$. Newport concentration returned to near the control concentration in the $\mathrm{pH} 10$ treatment whereas in the $\mathrm{pH} 10.3$ and 10.8 treatments the pathogen tended to be lower than in the control, and did not match those in the control until day 36.

For E. coli $\mathrm{O} 157: \mathrm{H} 7, \mathrm{pH} 4.0$ and 4.5 treatments effectively deactivated the pathogen as its concentration fell under the detection limit one day after the alum addition. At $\mathrm{pH} 4.9$, E. coli $\mathrm{O} 157: \mathrm{H} 7$ concentration was reduced by about $2.5 \log _{10}$ in the first day but it remained at that level for the rest of the experiment (Fig. 3A). As with the $S$. Newport experiments, the $\mathrm{pH} 11$ and 12 treatments were immediately lethal to E. coli O157:H7 (Fig. 3B), with none detected at the initial sampling time within 2 hrs of hydrated lime addition. At $\mathrm{pH} 10.0$, the initial measured concentration $\left(6.5 \log _{10}\right.$ CFU $\mathrm{g}^{-1}$ ) was not different from the unamended control, whereas in the $\mathrm{pH} 10.3$ and 10.8 treatments, initial concentrations were 5.2 and $5.1 \log _{10} \mathrm{CFU} \mathrm{g} \mathrm{g}^{-1}$, respectively. Between days 1 and 5, E. coli $\mathrm{O} 157: \mathrm{H} 7$ at $\mathrm{pH} 10.0$ to 10.8 declined gradually to $3 \log _{10} \mathrm{CFU} \mathrm{g} \mathrm{g}^{-1}$ and did not exhibit regrowth through day 14 , after which they could not be detected against the strong background growth of native manure microorganisms.

In practical terms, amounts of aluminum sulfate required to eliminate pathogens (i.e., mass of chemical to achieve lethal $\mathrm{pH}$ adjustment) from our dairy manure samples was 45 $\mathrm{g}$ alum $\mathrm{kg}^{-1}$ manure for $S$. Newport and $39 \mathrm{~g} \mathrm{~kg}^{-1}$ for $E$. coli O157:H7; comparable amounts of hydrated lime were $5.7 \mathrm{~g}$ $\mathrm{kg}^{-1}$ for both pathogens. Hydrated lime is clearly preferable on a mass-required basis, not considering possible increases in manure ammonia volatilization at high $\mathrm{pH}$. If we use an economic analysis similar to that in Diez-Gonzalez et al. [18], assuming annual manure production per lactating cow to be $20 \mathrm{Mg}$ [19] and current price per ton \$130 USD [20], $120 \mathrm{~kg}$ hydrated lime would be needed to eliminate Salmonella and E. coli. This corresponds to a cost of $\$ 16.80$ per cow per year, or $<5$ cents per day. If we calculate the amount of hydrated lime required to achieve $\mathrm{pH} 10$, which reduced E. coli $\mathrm{O} 157: \mathrm{H} 7$ by $>3$ log units (1000-fold), cost would be 3.5 cents per cow per day. Amendment of dairy manures with hydrated lime may be a simple, low-cost means to lessen pathogen loads on-farm and before landapplication of manures, and adds another technique to the toolkit needed to assure healthy animal and plant products in the human food sector.

At intermediate $\mathrm{pH}$, the lack of complete elimination of pathogens with some regrowth after the initial suppression of $S$. Newport and E. coli O157:H7 is a matter for concern. Both pathogens can cause disease at very low dose rates. Humphrey [21] reported infective doses of Salmonella sp. in foodstuffs to be in the range of 1 to 100 CFU. While infective dose of E. coli O157:H7 is not definitely known, Paton and Paton's review [22] suggests a similar infective dose of $100 \mathrm{CFU}$ or less. Particularly in the part of the population at higher risk of foodborne illness such as the very young, elderly, and those with compromised immune systems, temporary suppression of the pathogens by manure treatments without complete deactivation may not eliminate the possibility of contracting a foodborne disease if manures are allowed to contaminate the food production system.

\subsection{Temperature and $S$. Newport and $E$. coli $0157: H 7$ Deactivation}

$S$. Newport and E. coli $\mathrm{O} 157: \mathrm{H} 7$ responded similarly to temperature treatments except for the first few days of the experiment, in which E. coli $\mathrm{O} 157: \mathrm{H} 7$ showed 0.3 to $1 \mathrm{log}$ unit increase through day 7 at all three temperature treatments (Fig, 4A), while $S$. Newport either did not change or declined in concentration over the first 7 days of the incubation (Fig. 4B). At all three temperatures tested, both pathogens exhibited a log-linear decline phase, with deactivation rate constants between the two pathogens not significantly different at the $5 \%$ probability level (Table 2 ). This log-linear decline was observable in E. coli $\mathrm{O} 157: \mathrm{H} 7$ until day 62 at $22^{\circ} \mathrm{C}$ and day 91 at $4{ }^{\circ} \mathrm{C}$, after which strong background growth of native manure microorganisms prevented further detection of the inoculated $E$. coli. For $S$. Newport, the log-linear deactivation continued in the $22^{\circ} \mathrm{C}$ 

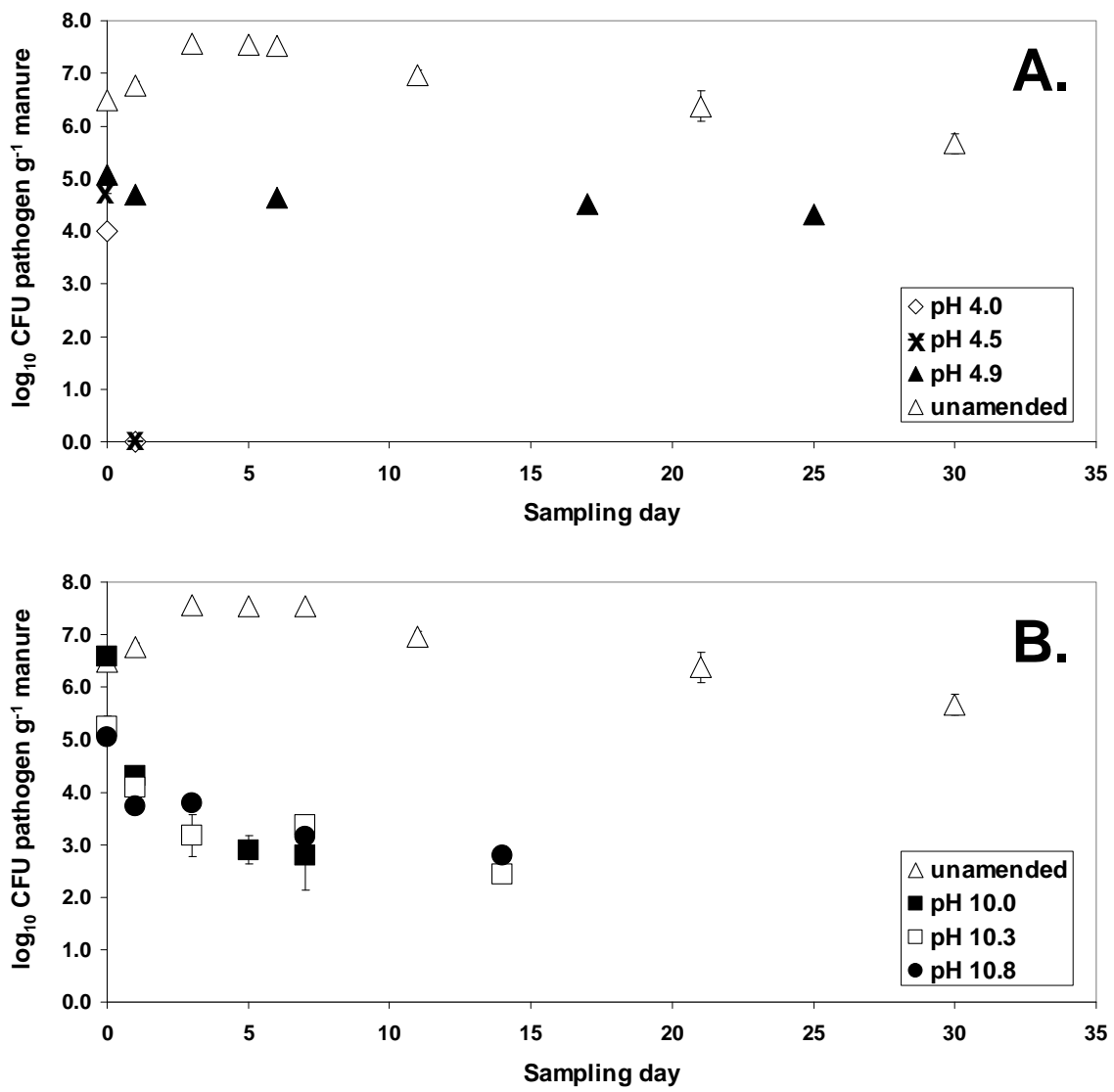

Fig. (3). E. coli $\mathrm{O} 157: \mathrm{H} 7$ response to low $\mathrm{pH}$ (alum, $\mathbf{A}$ ) and high $\mathrm{pH}$ (hydrated lime, B) amendment in dairy manure. Error bars represent \pm 1 standard error of the mean. Inoculated E. coli O157:H7 was immediately eliminated by the $\mathrm{pH} 11$ and 12 treatments, not detected at the initial pathogen enumeration within 2 hours of hydrated lime application.

treatment until the organism could no longer be detected for two sampling times (last observation on day 63 ). At $4^{\circ} \mathrm{C}, S$. Newport declined in a steady log-linear fashion to day 161 , but persisted at low concentrations until day 309 . At $37^{\circ} \mathrm{C}$, both pathogens disappeared rapidly, and were not found past day 7 for E. coli O157:H7 and day 13 for S. Newport. Log reduction times (LRT, the inverse of the slope of the linear portion of the deactivation curve, and variously referred to as D-value or DRT in the literature) for the two pathogens, were 1.4 to 2.5 days at $37^{\circ} \mathrm{C}, 10.4$ to 12.9 days at $22^{\circ} \mathrm{C}$, and 33.0 to 34.5 days at $4^{\circ} \mathrm{C}$.

\section{DISCUSSION}

A number of published reports have examined $\mathrm{pH}$ effects on suppression of pathogens in growth media. In a review paper on Salmonella response to environmental stress, Foster and Spector [23] suggested that minimum $\mathrm{pH}$ for growth in nutrient media was 4.3 for Salmonella Typhimurium and 4.6 for E. coli. This is comparable to our findings of lethal $\mathrm{pH}$ 4.2 for $S$. Newport and 4.5 for $E$. coli $\mathrm{O} 157: \mathrm{H} 7$ in inoculated dairy manure. In an early paper, Chung and Goepfert [24] noted that the minimum $\mathrm{pH}$ for growth of Salmonella serovar anatum in acidified nutrient broth ranged from 4.05 to 5.70. They found that at sub-lethal $\mathrm{pH}$ Salmonella was suppressed by 2 to $3 \log$ units, followed by recovery and regrowth, which is similar to the observations in the present study. Studies on acid tolerance in Salmonella have shown that the pathogen can be induced to survive at $\mathrm{pH}$ as low as 3.3 if they are first exposed to intermediate acid conditions.
This tolerance is DNA-mediated involving several genes [25].

To render biosolids and sewage sludges safe for land application, the U.S. Environmental Protection Agency has mandated use of a variety of treatments to achieve adequate reduction in pathogens from the biosolids materials (EPA Part 503 Biosolids Rule; [26]). The recommended alkaline treatment (lime stabilization) is for increasing the $\mathrm{pH}$ to $>12$ for $72 \mathrm{hrs}$ or longer. There have been studies of chemical amendments to sewage sludge for suppression of pathogen loads, Vinnerås et al. [27] found that urea effectively deactivated E. coli and Salmonella. Allievi et al. [9] noted that enteric bacteria in sewage sludges were eliminated within 2 weeks following treatment with $\mathrm{NH}_{4} \mathrm{OH}$ or $\mathrm{KOH}$, and resultant $\mathrm{pH}$ values of 10 to 10.5 , whereas acidification of sludge to $\mathrm{pH} 4$ had an equivalent, though slightly more rapid effect on pathogen elimination. Wong et al. [28] and Wong and Selvam [29] treated swine manure or biosolids with lime, calcium oxide or alkaline coal combustion byproducts. With an initial $\mathrm{pH}$ of 12 , Salmonella and total coliforms were removed from the biosolids within $2 \mathrm{hrs}$, and Salmonella and E. coli were eliminated in swine manure within 8 days.

Several studies have reported the effects of various chemical treatments on suppressing pathogens in animal manure. Ottoson et al. [30] treated bovine manure with urea or aqueous ammonia and suggested effective treatment rates and exposure times for eliminating Salmonella typhimurium 

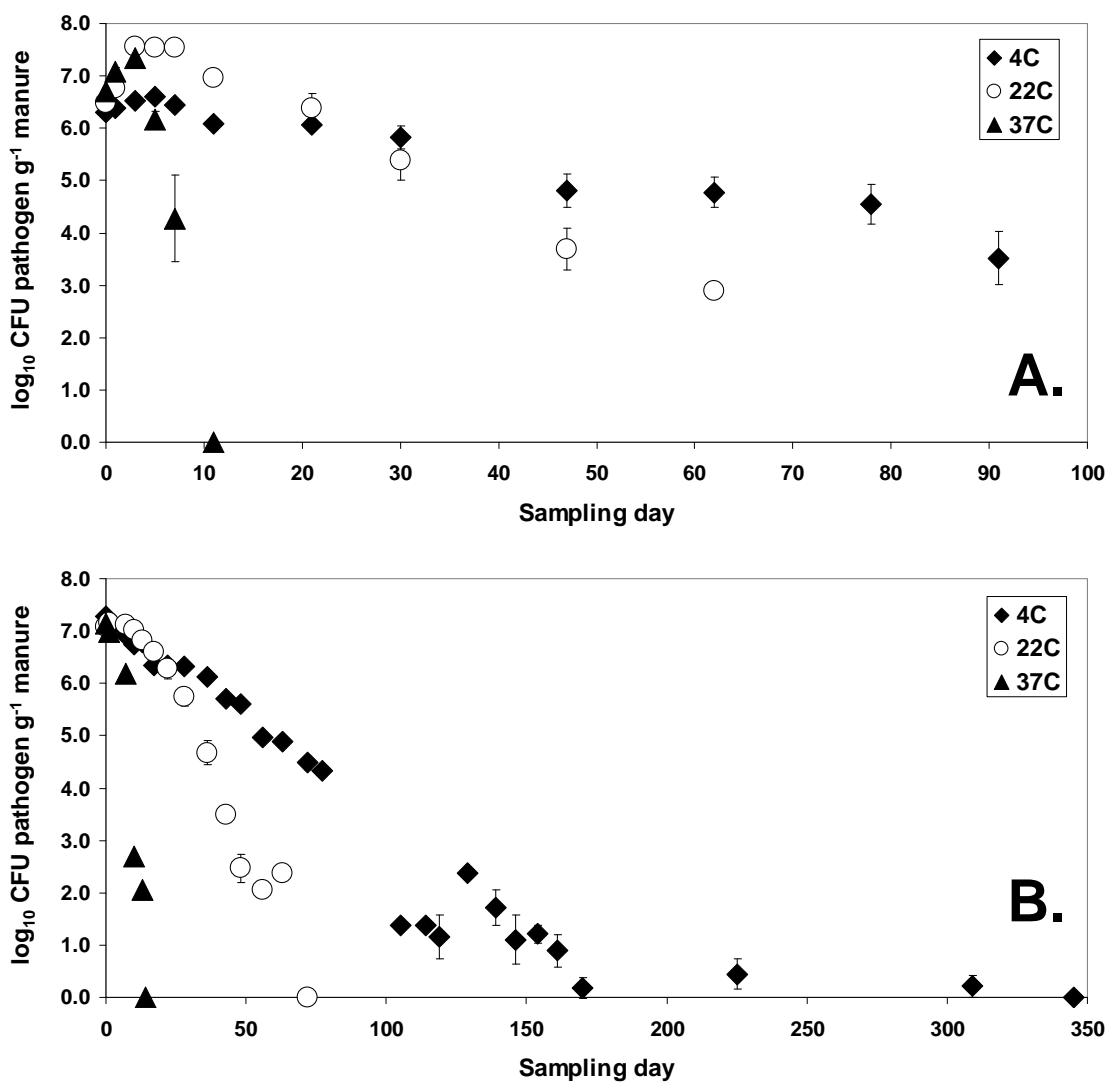

Fig. (4). E. coli $\mathrm{O} 157: \mathrm{H} 7$ (A) and S. Newport (B) survival response to incubation temperature in dairy manure. Error bars represent \pm 1 standard error of the mean.

to be 1 week with $0.5 \%$ ammonia treatment $(\mathrm{pH} 9.7)$ and 2 weeks with $2 \%$ urea $\left(\mathrm{pH} \mathrm{9.2)} \mathrm{at} 14^{\circ} \mathrm{C}\right.$. However, at $4{ }^{\circ} \mathrm{C}$ the required exposure time was 1 month. Arthurs et al. [31] tested different carbonate-generating chemicals to determine their ability to reduce $E$. coli viability in dairy manure slurries. Sodium carbonate at an application rate of $16 \mathrm{~g} \mathrm{~kg}^{-1}$ reduced $E$. coli from $6 \log _{10} \mathrm{~g}^{-1}$ to the detection limit of 1 $\log _{10} \mathrm{~g}^{-1}$ within 5 days. Although the threshold $\mathrm{pH}$ for pathogen deactivation was lower in their study $(\cong 10.0)$ than that in the present study $(>10.8)$, Arthurs et al. also noted a similar effect on $E$. coli at intermediate $\mathrm{pH}$, between 9 and 10 , which suppressed $E$. coli by up to $3 \log$ units without complete elimination. Park and Diez-Gonzalez [32] inoculated dairy manure adjusted to $\mathrm{pH} 9.5$ with $\mathrm{NaOH}$, then supplemented the $\mathrm{pH}$-adjusted manure with ammonium chloride, urea or sodium carbonate. E. coli O157:H7 and Salmonella Typhimurium concentrations were reduced by up to $6 \log _{10} \mathrm{~g}^{-1}$. In general, modifying manure or biosolids materials to $\mathrm{pH}$ in the range 10 to 12 is shown in published studies as well as the present research to be effective in rapid elimination of several pathogen species, although the lethal $\mathrm{pH}$ and rate of pathogen destruction may vary.

Reports in the literature agree that the duration of pathogen survival in animal manures and biowastes is generally greater at low temperatures than at high ones, although deactivation rates vary by species and experimental

Table 2. Regression Equation Parameters for the Log-Linear Decline Phase, Comparison Between E. coli O157:H7 and S. Newport Responses to Incubation of Dairy Manure at Three Temperatures

\begin{tabular}{|cccccc|}
\hline Temperature & Pathogen Species & Slope & Y-Intercept & R $^{2}$ & Log Reduction Time (Days) $^{\mathbf{a}}$ \\
\hline \hline $4^{\circ} \mathrm{C}$ & E. coli O157:H7 & -0.0290 & $6.64 \mathrm{a}$ & 0.97 & 34.5 \\
& S. Newport & -0.0303 & $6.47 \mathrm{a}$ & 0.89 & 33.0 \\
$22^{\circ} \mathrm{C}$ & E. coli O157:H7 & -0.0773 & $7.92 \mathrm{a}$ & 0.98 & 12.9 \\
& S. Newport & -0.0963 & $7.89 \mathrm{a}$ & 0.94 & 0.4 \\
$37^{\circ} \mathrm{C}$ & E. coli O157:H7 & -0.7377 & $9.66 \mathrm{~b}$ & 7.82 & 2.4 \\
& S. Newport & -0.3957 & $7.80 \mathrm{a}$ & 0.89 & 2.5 \\
\hline
\end{tabular}

${ }^{a}$ Log reduction time is the number of days over which pathogen concentration declines by 10 -fold. It is calculated as the inverse of the deactivation rate constant, the slope of the linear regression equation.

Values for the same regression parameter and temperature followed by the same letter are not significantly different at the $5 \%$ probability level by Fisher's protected lsd test following least-squares analysis of variance. 
conditions. Himathongkham et al. [33] incubated cow manure inoculated with Salmonella serovar typhimurium and E. coli $\mathrm{O} 157: \mathrm{H} 7$ at 6 to $8 \log _{10} \mathrm{CFU} \mathrm{g} \mathrm{g}^{-1}$ and found decimal reduction times of 1.7 to 3.8 days, 9.4 to 13.5 days, and 18.6 to 20.3 days at 37,22 and $4^{\circ} \mathrm{C}$, respectively. Hutchison et al. [34] studied the survival of four pathogen species in large tanks outdoors under summer and winter temperatures, and determined the seasonal LRT values. Log reduction times for Salmonella in stored dairy manure over winter (average temperature $4.3^{\circ} \mathrm{C}$ ) were 7.3 to 11.8 days, and 6.8 to 8.9 days in summer (average temperature $12.4^{\circ} \mathrm{C}$ ).

Raising manure temperature may be an effective way to reduce potential pathogen loadings to the environment. For example, manure composting is a frequently-employed means to reduce pathogen concentrations before land application. Temperatures of $55^{\circ} \mathrm{C}$ maintained for 2 to 3 days is generally considered to be sufficient to suppress or eliminate most pathogens [35]. At sub-lethal temperatures, however, evidence for effective deactivation of pathogens is equivocal. Fremaux et al. [36] and Wang et al. [37] noted survival of $E$. coli $\mathrm{O} 157: \mathrm{H} 7$ for several months at 35 to $37^{\circ} \mathrm{C}$, whereas in the present study $S$. Newport and E. coli O157:H7 were not found after 14 days incubation at $37^{\circ} \mathrm{C}$.

\section{CONCLUSION}

Using hydrated lime or aluminum sulfate, the foodborne pathogens Salmonella serovar Newport and E. coli O157:H7 could be effectively eliminated from dairy manure by altering the manure's $\mathrm{pH}$ regime to $\leq 4.2$ to 4.5 , or $\geq 11$. Amendment with hydrated lime may be a better practical option since the amount needed to achieve a given $\mathrm{pH}$ is less than with alum. Similarly, the pathogens were deactivated within 2 weeks by increasing the temperature of inoculated manure to $37^{\circ} \mathrm{C}$. Meanwhile, spreading manure in cold seasons in temperate climate conditions can have an elevated risk of pathogen dissemination.

\section{ACKNOWLEDGEMENT}

We would like to thank Xijuan (Joanne) Gui and Jesse Vanderhoef for material support in conducting the laboratory trials, and the Microbiology Laboratory staff of the University of Pennsylvania School of Veterinary Medicine at New Bolton Center for essential help in interpreting research results. The project was supported by USDA-NRI competitive grant 2007-35102-1824.

\section{CONFLICT OF INTEREST}

Declared none.

\section{REFERENCES}

[1] Centers for Disease Control and Prevention, "CDC 2011 estimates: Findings", 2011. Available online: visited on 28 March 2012. http://www.cdc.gov/foodborneburden/2011-foodborne-estimates.html

[2] S. Clark, "Salmonella Newport - An emerging disease in dairy cattle", Indiana Animal Disease Diagnostic Laboratory, Summer 2004 Newsletter. Available online: visited on 28 March 2012. http://www.addl.purdue.edu/newsletters/2004/summer/salmnewp.htm

[3] H. S. Hussein and T. Sakuma, "Prevalence of shiga toxinproducing Escherichia coli in dairy cattle and their products", $J$. Dairy Sci., vol. 88, pp. 450-465, 2005.

[4] A. Rodriguez, P. Pangloli, H. A. Richards, J. R. Mount, and F. A. Draughon, "Prevalence of Salmonella in diverse environmental farm samples", J. Food Prot., vol. 69, pp. 2576-2580, 2006.
M. B. Jenkins, M. J. Walker, D. D. Bowman, L. C. Anthony, and W. C. Ghiorse, "Use of a sentinel system for field measurements of Cryptosporidium parvum oocyst inactivation in soil and animal waste", Appl. Environ. Microbiol., vol. 65, pp. 1998-2005, 1999.

[6] J. D. Toth, H. W. Aceto, S. C. Rankin, and Z. Dou, "Survival characteristics of Salmonella enterica serovar Newport in a dairy lagoon, field soil, and compost pile", J. Dairy. Sci., vol. 94, pp. 5238-5246, 2011.

[7] U.S. Food and Drug Administration (US FDA), "Food: Hazard Analysis \& Critical Control Points (HACCP)", 2011. Available online: visited on 28 March 2012. http://www.fda.gov/Food/FoodS afety/HazardAnalysisCriticalControlPointsHACCP.default.htm

[8] M. J. Rothrock, Jr., K. L. Cook, J. G. Warren, and K. Sistani, "The effect of alum addition on microbial communities in poultry litter", Poultry Sci., vol. 87, pp. 1493-1503, 2008.

[9] L. Allievi, A. Colombi, E. Calcaterra, and A. Ferrari, "Inactivation of fecal bacteria in sewage sludge by alkaline treatment", Bioresour. Technol., vol. 49, pp. 25-30, 1994.

[10] Z. Dou, G. Y. Zhang, W. L. Stout, J. D. Toth, and J. D. Ferguson, "Efficacy of alum and coal combustion by-products in stabilizing manure phosphorus", J. Environ. Qual., vol. 32, pp. 1490-1497, 2003.

[11] J. D. Wilson, V. D. Zheljazkov, B. Rathgeber, D. D. Caldwell, and D. L. Burton, "Reduction in phosphorus availability in poultry and dairy manure by mineral amendments", Soil Sci. Plant Nutr., vol. 54, pp. 600-605, 2008.

[12] M. A. Kristula, Z. Dou, J. D. Toth, B. I. Smith, N. Harvey, and M. Sabo, "Evaluation of free-stall mattress bedding treatments to reduce mastitis bacterial growth", J. Dairy Sci., vol. 91, pp. 1885$1892,2008$.

[13] M. C. Erickson, J. Liao, L. Ma, X. Jiang, and M. P. Doyle, "Pathogen inactivation in cow manure compost", Compost Sci. Util., vol. 17, pp. 229-236, 2009.

[14] Y. You, S. C. Rankin, H. W. Aceto, C. E. Benson, J. D. Toth, and Z. Dou, "Survival of Salmonella enterica serovar Newport in manure and manure-amended soils", Appl. Environ. Microbiol., vol. 72, pp. 5777-5783, 2006.

[15] P. M. Fratamico, M. Y. Deng, T. P. Strobaugh, and S. A. Palumbo, "Construction and characterization of Escherichia coli O157:H7 strains expressing firefly luciferase and green fluorescent protein and their use in survival studies", J. Food Prot., vol. 60, pp. 11671173, 1997.

[16] U.S. Food and Drug Administration, "BAM Appendix 2: Most Probable Number from Serial Dilutions", 2006. Available online: visited on 28 March 2012. http://www.fda.gov/Food/ScienceResea $\mathrm{rch} /$ LaboratoryMethods/BacteriologicalAnalyticalManualBAM/uc m109656.htm

[17] SAS Institute, The SAS system for Windows, Release 9.2, SAS Inst., Inc., Cary, NC 2007.

[18] F. Diez-Gonzalez, G. N. Jarvis, D. A. Adamovich, and J. B. Russell, "Use of carbonate and alkali to eliminate Escherichia coli from dairy cattle manure", Environ. Sci. Technol., vol. 34, pp. 1275-1279, 2000.

[19] American Society of Agricultural and Biological Engineers (ASABE), "Manure Production and Characteristics", ASABE Standards D384.2 MAR2005 (R2010), ASABE-The Society for engineering in agricultural, food and biological systems, St. Joseph, MI, 2005.

[20] U.S. Geological Survey (USGS), "Mineral Commodity Summaries: Lime", 2011. Available online: visited on 28 March 2012. http://minerals.usgs.gov/minerals/pubs/mcs/2011/mcs2011.pdf

[21] T. Humphrey, "Salmonella, stress responses and food safety", Nat. Rev. Microbiol., vol. 2, pp. 504-509, 2004.

[22] J. C. Paton and A. W. Paton, "Pathogenesis and diagnosis of shiga toxin-producing Escherichia coli infections", Clin. Microbiol. Rev., vol. 11 , pp. 450-479, 1998.

[23] J. W. Foster and M. P. Spector, "How Salmonella survive against the odds", Annu. Rev. Microbiol, vol. 49, pp. 145-174, 1995.

[24] K. C. Chung and J. M. Goepfert, "Growth of Salmonella at low pH”, J. Food Sci, vol. 35, pp. 326-328, 1970.

[25] J. W. Foster and H. K. Hall, "Adaptive acidification tolerance response of Salmonella typhimurium", J. Bacteriol., vol. 172, pp. 771-778, 1990.

[26] U.S. Environmental Protection Agency, "A Plain English Guide to the EPA Part 503 Biosolids Rule, Chapter 5, Pathogen and Vector Attraction Reduction Requirements" (1984) Available online: 
visited on 28 March 2012. http://www.epa.gov/npdes/pubs/503 pe_5.pdf

[27] B. Vinnerås, A. Holmqvist, E. Bagge, A. Albihn, and H. Jönsson, "The potential for disinfection of separated faecal matter by urea and by peracetic acid for hygienic nutrient recycling", Bioresour. Technol., vol. 89, pp. 155-161, 2003.

[28] J. W. C. Wong, M. Fang, and R. Jiang, "Persistency of bacterial indicators in biosolids stabilization with coal fly ash and lime", Water Environ. Resear., vol. 73, pp. 607-611, 2001.

[29] J. W. C. Wong and A. Selvam, "Reduction of indicator and pathogenic microorganisms in pig manure through fly ash and lime addition during alkaline stabilization", J. Hazard Mater., vol. 169, pp. 882-889, 2009.

[30] J. Ottoson, A. Nordin, D. von Rosen, and B. Vinnerås, "Salmonella reduction in manure by the addition of urea and ammonia", Bioresour. Technol., vol. 99, pp. 1610-1615, 2008.

[31] C. E. Arthurs, G. N. Jarvis, and J. B. Russell, "The effect of various carbonate sources on the survival of Escherichia coli in dairy cattle manure", Curr. Microbiol., vol. 43, pp. 220-224, 2001.

[32] G. W. Park and F. Diez-Gonzalez, "Utilization of carbonate and ammonia-based treatments to eliminate Escherichia coli $\mathrm{O} 157: \mathrm{H} 7$ and Salmonella Typhimurium DT104 from cattle manure", J. Appl. Microbiol., vol. 94, pp. 675-685, 2003.

[33] S. Himathongkham, S. Bahari, H. Riemann, and D. Cliver, "Survival of Escherichia coli $\mathrm{O} 157: \mathrm{H7}$ and Salmonella typhimurium in cow manure and cow manure slurry", FEMS Microbiol. Lett., vol. 178, pp. 251-257, 1999.

[34] M. L. Hutchison, L. D. Walters, A. Moore, and S. M. Avery, "Declines of zoonotic agents in liquid livestock wastes stored in batches on-farm", J. Appl. Microbiol., vol. 99, pp. 58-65, 2005.

[35] K. J. Zaleski, K. L. Josephson, C. P. Gerba, and I. L. Pepper, "Survival, growth, and regrowth of enteric indicator and pathogenic bacteria in biosolids, compost, soil, and land applied biosolids", $J$. Resid. Sci. Tech., vol. 2, pp. 49-63, 2005.

[36] B. Fremaux, M. L. Delignette-Muller, C. Prigent-Combaret, A Gleizal, and C. Vernozy-Rozand, "Growth and survival of nonO157:H7 Shiga-toxin-producing Escherichia coli in cow manure", J. Appl. Microbiol., vol. 102, pp. 89-99, 2007.

[37] G. Wang, T. Zhao, and M. P. Doyle, "Fate of enterohemorrhagic Escherichia coli O157:H7 in bovine feces", Appl. Environ. Microbiol., vol. 62, pp. 2567-2570, 1996.

This is an open access article licensed under the terms of the Creative Commons Attribution Non-Commercial License (http://creativecommons.org/licenses/by$\mathrm{nc} / 3.0 /$ ) which permits unrestricted, non-commercial use, distribution and reproduction in any medium, provided the work is properly cited. 